日臨外会誌 $63(4), 927-931,2002$

症例

腹腔鏡下回盲部切除術を行った虫垂杯細胞カルチノイド (goblet cell carcinoid) の2 例

\begin{tabular}{llllllll}
\multicolumn{8}{c}{ 長野市民病院外科 } \\
村 & 真 & 基 & 宗 & 像 & 康 & 博 林 & 賢 \\
西 & 村 & 秀 & 紀 & 町 & 田 & 恵 & 美
\end{tabular}

急性虫垂炎で発症した虫垂杯細胞カルチノイドの 2 例を経験した。症例 1 は35歳の男 性. 右下腹部痛を主訴に来院し，急性虫垂炎の診断で虫垂切除術を行った。病理組織学 的に急性虫垂炎と独立して杯細胞カルチノイドの合併を認めた。腫瘍細胞の固有筋層へ の浸潤を認めたため, 初回手術後37日目に腹腔鏡補助下 2 群郭清回盲部切除術を行った。 追加切除標本には腫崵細胞を認めなかった，症例 2 は76歳の女性．右下腹部痛を主訴に 来院し，急性虫垂炎の診断で虫垂切除術を行った，病理組織学的に急性虫垂炎とともに 杯細胞カルチノイドの合併を認めた。切除断端部に腫湟の遺残を認めたため, 初回手術 後14日目に腹腔鏡補助下 2 群郭清回盲部切除術を行った。追加切除標本の病理組織診断 で1群リンパ節 1 個に転移を認めた. 2 例とも術後 5 年経過して再発を認めていない. 虫垂切除術後の病理組織学的検索の重要性が再確認された。

索引用語：虫垂, 杯細胞カルチノイド

\section{緒言}

虫垂カルチノイドは虫垂切除術200〜300例に1例の 割合で存在し, 銀還元性, 好銀性, 杯細胞性の 3 亚型 に分類されている．杯細胞カルチノイドは虫垂のみに 存在し, カルチノイド類似像と腺癌類似像を共有する 稀な腫場で, 予後不良と考えられている. 今回われわ れは, 急性虫垂炎の診断で虫垂切除術を施行し, 病理 組織学的に本腫暗を確認された 2 例を経験した。いず れも腹腔鏡補助下回盲部切除術を追加して行い, 術後 5 年経過し再発を認めないので, 若干の文献的考察を 加えて報告する。

症例 $1 ： 35$ 歳, 男性.

\section{症例}

主訴：右下腹部痛.

家族歴・既往歴：特記すべきことなし.

現病歴：1995年 8 月から 8 力月間に 3 回の右下腹部 痛を認めて近医を受診し，急性虫垂炎の診断でいずれ も3 日間程度抗生剂を内服し軽快していた。1996年 4

2001年10月15日受付 2002年1月15日採用

〈所属施設住所〉

テ381-8551 長野市大字富竹1333- 1
月11日より右下腹部痛を認め近医を受診し，抗生郕 (OFLX)を 3 日間服用したが軽快せず，4 月15日，手 術目的に当科紹介受診となった。

入院時現症：身長 $164 \mathrm{~cm}$, 体重 $55 \mathrm{~kg}$, 体温 $37.1^{\circ} \mathrm{C}$. 全身状態に問題なし.腹部に McBurney 点を最強とす る压痛を認めた。

入院時検查成績: 白血球数 $6,700 / \mathrm{mm}^{3}$ と正常化し ており，他にも異常值を認めなかった。

腹部超音波検查所見：直径 $17 \mathrm{~mm}$ に腫大した虫垂を 認めた（図 1 ）。

白血球数は正常化していたが，超音波検㚗所見，繰 り返す虫垂炎症状と本人の希望加手術適応と判断 し，4月16日に手術を行った。

手術所見：開腹時，少量の腹水を認めたが混濁は認 めなかった。虫垂は上行結腸の外側に瘉着し末梢側は 著明に腫大，今回の穿孔は認めなかったが，以前穿孔

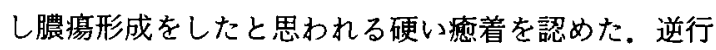
性に虫垂切除を行い，ドレーンを留置して閉腹した。

切除標本：虫垂末梢側は著明に腫大し蜂巣炎一壊疽 性虫垂炎と考えられたが，腫演を示唆する所見には乏 しかった.

病理組織学的所見：摘出された虫垂の体部から頸部 


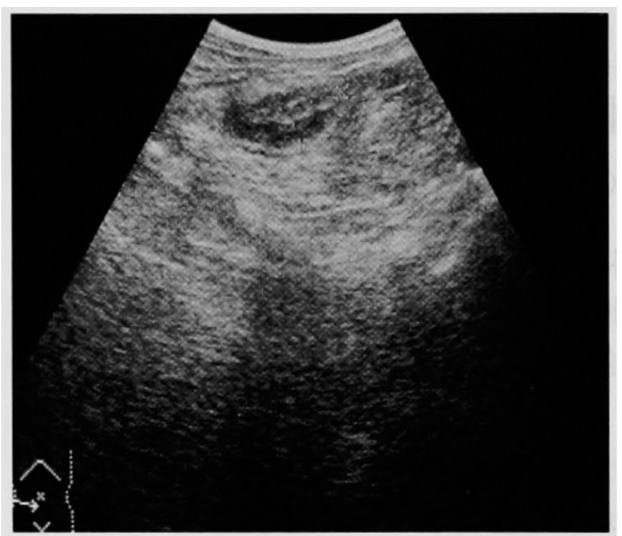

図 1 腹部超音波検査所見 (症例 1 ) : 直径 $1.7 \mathrm{~cm}$ 大に腫大した虫垂を認める。

にかけ，全周に渡り杯細胞カルチノイドを認め，主と して粘膜下から固有筋層下層にかけて浸潤していた。 一部は粘膜固有層にも認められた(図 2 )。切除断端部 には腫瘍細胞を認めなかった，Factor-VIII 免疫染色 では脈管浸潤は明らかでなかった。

また腫湯とは独立して，虫垂底部に蜂巣炎性の急性 虫垂炎を認め, 好中球を含む炎症性細胞浸潤は外膜に まで及んでいた。

術後経過良好で一度退院したが, 病理組織診断を受 け臨床的に癌と同様に扱うこと, 深達度が固有筋層に まで及んでいることより，追加手術が必要と考え，精 查を行った。

上部消化管内視鏡検査所見：特に異常所見を認めな かった。

注腸造影検査所見：虫垂が切除されていること以外 には異常所見を認めなかった。

大晹内視鏡検查所見：直腸に小ポリープを認めた （生検で腺腫と診断）が，その他には盲腸を含めて異 常所見を認めなかった。

腹部 CT 検査所見：転移，浸潤を疑わせる所見は認 めなかった。

初回手術後37日目に第 2 回手術を行った.

第 2 回手術所見：手術は腹腔鏡補助下回盲部切除術 を行った，腹腔鏡下に結腸を授動し，回結腸動静脈根 部まで歌清した（2群郭清）（図 3 ），前回の虫垂切除 術創に一致させて小開腹をおき，回盲部を創外にて切 除再建した.202番リンパ節 5 個を術中迅速病理診断に 提出したが，腫瘍の転移は認めなかった。

切除標本：切除された回盲部には肉眼的に腫瘍の遺 残,リンパ節腫大を認めなかった。

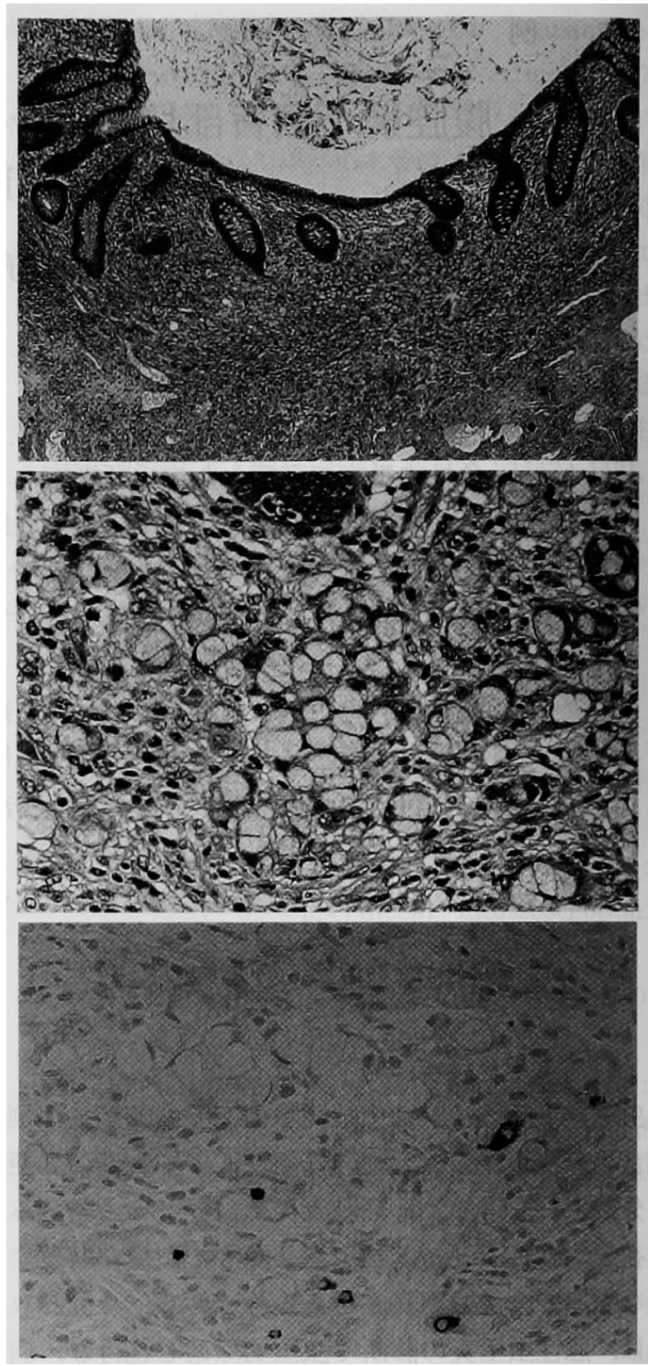

図 2 病理組織学的所見 (症例 1)：印鑑細胞類似の 腫瘍細胞を粘膜固有層から固有筋層までに認める (A：HE染色, $\times 16, B$ ：同染色, $\times 100)$. chromogranin-A 陽性顆粒を有する小型の腫瘍細 胞が混在している（C； chromogranin-A 染色, Blue filter, $\times 100)$.

$$
\frac{\mathrm{A}}{\mathrm{B}}
$$

病理組織学的所見 : 肉眼所見同様, 腫瘍細胞の遺残, リンパ節転移は認めなかった。

術後経過：経過良好で, 術後11日目に退院した。術 後 5 年経過し再発徵候を認めない。

症例 $2: 76$ 歳, 女性.

主訴：右下腹部痛.

家族歴・既往歴：特記すべきことなし。 
現病歴：1996年 8 月 1 日より心窩部痛, $38.0^{\circ} \mathrm{C}$ 発 熱を認めた。 8 月 4 日には右下腹部痛を認め近医より 当科紹介受䛦となった.

入院時現症：身長 $141 \mathrm{~cm}$, 体重 $40 \mathrm{~kg}$, 体温 $37.1^{\circ} \mathrm{C}$. 全身状態に問題なし. 腹部に McBurney 点付近を最強 とする圧痛と Blumberg 徵候を認めた。

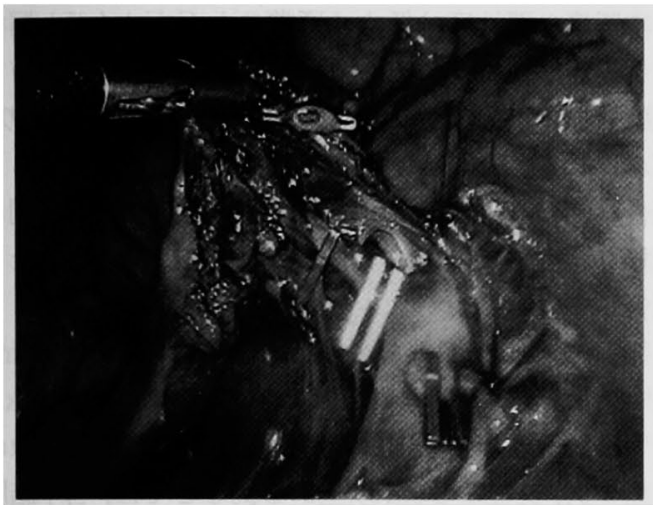

図 3 術中所見（症例 1 ）：回結腸動脈は根部で二重 クリップの後切離され，回結腸静脈は surgical trunk を露出して根部でクリップされている.
入院時検査成績：白 血 球 数 $9,300 / \mathrm{mm}^{3}$, CRP 5.4 $\mathrm{mg} / \mathrm{dl}$ ，他に異常值はなかった。

腹部超音波検査所見：直径 $10 \mathrm{~mm}$ に腫大した虫垂を 認めた。

以上より急性虫垂炎と診断し保存的治療を開始した が，翌 5 日になっても症状に改善がみられないため， 同日手術を行った。

手術所見：開腹時，腹水は認めなかった，虫垂は上 行結腸に癒着し腫大発赤していた。順行性に虫垂切除 を行った。

切除標本：虫垂は長さ $4.5 \mathrm{~cm}$, 発赤腫大し蜂巣炎性 虫垂炎と考えられたが，腫愓を示唆する所見には乏し かった。

病理組織学的所見：虫垂頸部体部に核が遍在する腫 瘍細胞を認め，粘膜内から漿膜下組織にまで達し，杯 細胞カルチノイドと診断された(図 4)，切除断端部に 腫瘍細胞を認めた，脈管侵殐像は認めなかった。虫垂 底部には上皮の脱落と獎膜下にまで達する炎症性細胞 浸潤を認め，急性虫垂炎の所見であった。

病理組織診断により追加手術が必要とされたため, 引き続き入院し諸検査を行った。
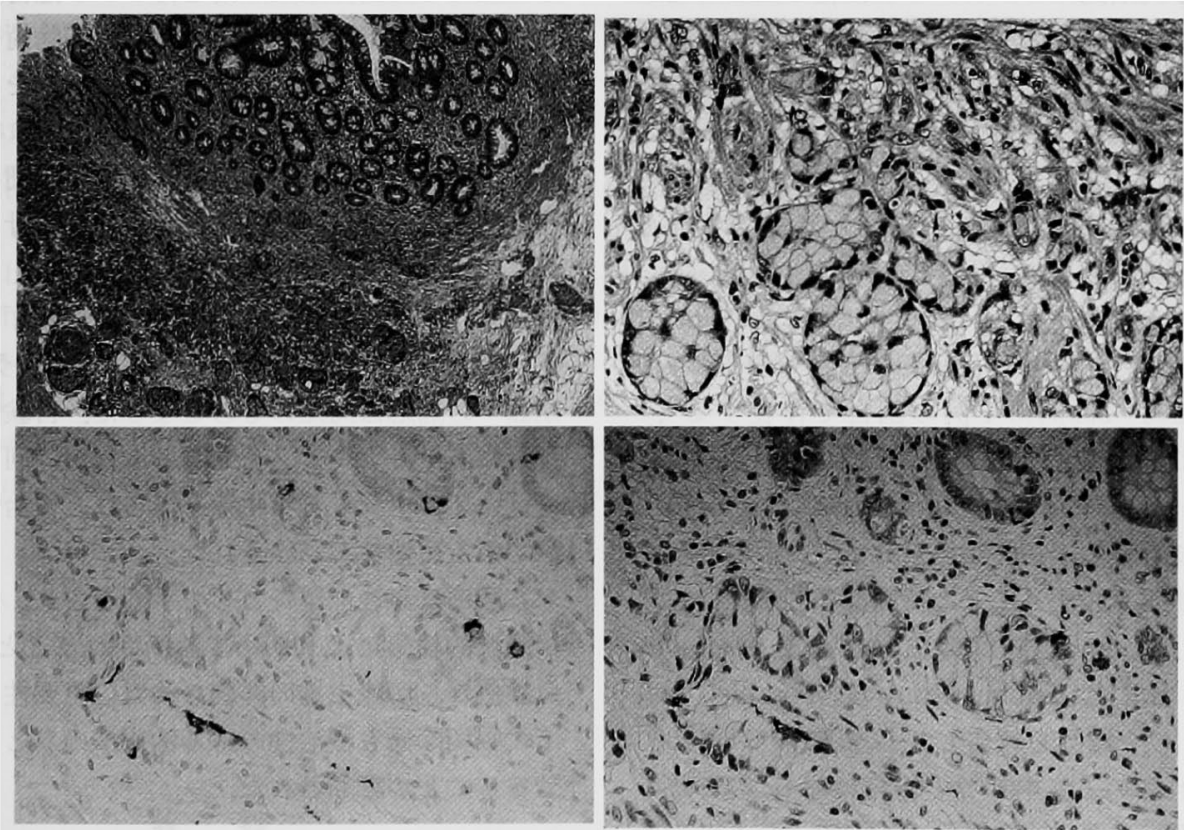

図 4 病理組織学的所見（症例 2 ）：印環細胞様の腫㿇細胞が小型の nest を形成して浸潤性に増 殖し，漿膜下組織にまで達している(A；HE 染色，×16，B；同染色，×1011)，免疫組織化学的 $k$ chromogranin-A が証明される（C； chromogranin-A 染色, Blue filter, $\times 100, D$; 同染 色, Green filter, $\times 100$ ).

\begin{tabular}{l|l}
$\mathrm{A}$ & $\mathrm{B}$ \\
\hline $\mathrm{C}$ & $\mathrm{D}$
\end{tabular} 
上部消化管内視鏡検查所見 : 特に異常所見を認めな かった。

注腸造影検査所見：虫垂は切除され，盲腸先端部に $1 \mathrm{~cm}$ 大の隆起病変を認めた。

大腸内視鏡検查所見：注腸で指摘された盲腸先端の 小隆起は発赤を伴い虫垂切除の影響と考えられたが， 同部位からの生検でカルチノイド細胞が検出された。 他に異常所見を認めなかった。

腹部 CT 検查所見：転移，浸潤を疑わせる所見は認 めなかった。

初回手術後14日目に第 2 回手術を行った。

第 2 回手術所見 : 手術は腹腔鏡補助下回盲部切除術 を行った。症例 1 と同样に腹腔鏡下に結腸を授動し， 回結腸動静脈および右結腸動静脈の根部まで郭清した (2 群郭清). 回盲部の切除再建は小開腹をおき創外て 行った.202番リンパ節を術中迅速病理診断に提出した が，腫佰の転移は認めなかった。

切除標本：切除された回盲部には肉眼的に腫場の遺 残は明らかでなかった。術前内視鏡検査で指摘された 発赤隆起は虫垂切除術の影響と考えられ，切除標本で は消退していた。

病理組織学的所見：カルチノイド細胞は虫垂断端部 にのみ遺残し，盲腸への浸潤は認めなかった１群り ンパ節（201番）にカルチノイド細胞の転移を認めた (1/10) が，2 群リンパ節には転移を認めなかった $(0 / 5)$.

術後経過：経過良好で軽快退院した. 術後 5 年経過 し，再発を認めていない。

\section{考察}

虫垂カルチノイドは虫垂腫瘍の50〜77\%をしめ", 虫垂切除術200〜300例に 1 例の割合で存在する 2 . WHO 分類では銀還元性, 好銀性, 杯細胞性の 3 亚型に 分類されている ${ }^{3)}$. 杯細胞性 (goblet cell carcinoid) は虫垂のみに存在し，1969年に Gagne ら'が粘液産生 能を有する虫垂カルチノイドの特殊型 3 例を報告した のに始まる，Klein ${ }^{5}$ が同様の虫垂腫煌を mucinous carcinoid と名付け, Subbuswamy $ら^{6}{ }^{6}$ が goblet cell carcinoid として12例を報告して以来欧米では140例 以上報告されている。本邦での報告は彭らつの1998年 の集計（49例）に医学中央雑誌で検索できたものを加 え71例である。組織学的には, 粘液産生性で, 細胞異 型に乏しく，杯細胞あるいは印睘細胞類似の細胞が胞 巣状, 腺房状, 索状の構造をとって增殖し, 全層性の 浸潤をすること，粘膜被覆上皮には悪性所見がそしい
ことなどが特徵とされている゙. 自験例 2 例では，いず れも杯細胞あるいは印環細胞類似の腫瘍細胞が豊富な 粘液を有し，症例 1 では粘膜固有層から固有筋層下層 に浸潤し，症例 2 では一部粘膜内に腫瘍の浸潤を認め たが，主として粘膜固有層から瀪膜下組織に浸潤がみ られた。また自験例ではいずれも免疫組織化学的に腫 漡細胞内に chromogranin-A が証明された。

本腫瘍の悪性度は低く，通常のカルチノイドと同様 の予後が期待できるとした報告もあるが4ー6)，一方で 腹膜播種 ${ }^{3)}$ 即巣転移")として発見された症例もあり, Warkel ら ${ }^{10}$ は本腫場の $20 \%$ は転移により死に至ると 報告している。 また Butler らのは本腫場 9 例中 5 例に 転移を認め,このうち 4 例は 24 力月以内に死亡したと 報告している。

徉って本腫瘍の治療法については，Subbuswamy ら ${ }^{6}$ は虫垂切除術のみで良いとしているが, Warkel $ら^{100}$ は虫垂以外に浸潤した例や，異型性や核分裂像の 目立つ例, 長径が $2 \mathrm{~cm}$ 以上ある例などでは, 右半結腸 切除術を行うべきとし, Edmonds ら ${ }^{11}$ は癌に近いとい う性質から右半結腸切除術を推奖している。また Butler ら”は虫垂にびまん性に広がる例では右半結腸切 除に加えて両側卵巣摘除術を行うよう進言している。 報告症例数の蓄積に伴い，右半結腸切除術を標準的に 行う傾向であると思われる．本邦報告例をまとめた彭 らクによると, 回盲部切除や右半結腸切除など郭清を 伴う手術は $64 \%$ にのほるがその成績の詳細は不明であ り，報告例が少ないこともあり，治療方針を厳密に定 めるには至っていない.

1991年より臨床応用されている腹腔鏡下大腸切除 術 ${ }^{12)}$ は, 上うやく長期成績が報告されるようになり, 早 期癌への適応は周知のものとなった。自験例 2 例は進 行癌にあたるカルチノイドであったが, 回盲部切除術 を行っていずれも 5 年生存を得られ，根治性のある治 療である可能性が示唆された。

本腫瘍は急性虫垂炎として手術をされ，術後の病理 組織学的検索により初めて診断されることが多い》. 自験例から切除虫垂の詳細な検索の重要性と, 腹空鏡 下大腸切除術も根治性のある治療法のひとつの選択肢 であることが認識された。

\section{結 語}

虫垂杯細胞カルチノイドの 2 例を報告し，若干の文 献的考察を加えて検討した。 


\section{文献}

1) Lyss AP : Appendiceal malignancies. Semin Oncol $15: 129-137,1988$

2) Moertel CG:An odyssey in the land of small tumors. J Clin Oncol $5: 1503,1987$

3) WHO:Histological Typing of Intestinal Tumor. No. 15, WHO, Geneva, 1976, p54-55

4) Gagne F, Fortin P, Dufour V, et al : Tumeurs de l'appendice associant des caracteres histologiques de carcinoid et d'adenocarcinome. Ann Anat Pathol 14:393-406, 1969

5) Klein $\mathrm{HZ}$ : Mucinous carcinoid tumor of the vermiform appendix. Cancer $33: 770-777$, 1974

6) Subbuswamy SG, Gibbs NM, Ross CF, et al : Goblet cell carcinoid of the appendix. Cancer $34: 338-344,1974$

7）彭 英峰，山田克己，国府育决他：虫垂 goblet cell carcinoid の 1 例. 日臨外会誌 $59: 2323-2326$, 1998

8) Wolff $M$, Ahmed $N$ : Epithelial neoplasma of the vermiform appendix (exclusive of carcinoid. 1. Adenocarcinoma of the appendix). Cancer $37: 2497-2510,1976$

9) Butler JA, Houshiar A, Lin F, et al : Goblet Cell Carcinoid of the Appendix. Am J Surg 168: 685 $-687,1994$

10) Warkel RL, Cooper PH, Helwig EB : Adenocarcinoid, a mucin-producing carcinoid tumor of the appendix. A study of 39 cases. Cancer 42 : 2781-2793, 1978

11) Edmonds P, Merino MJ. Livolsi VA, et al: Adenocarcinoid (mucinous carcinoid) of the appendix. Gastroenterology $86: 302-309,1984$

12）林賢, 宗像康博 : 腹腔鏡下大腸切除術. 日臨 $54: 1312-1321,1996$

\title{
TWO CASES OF GOBLET CELL CARCINOID OF THE APPENDIX PERFORMED A LAPAROSCOPY ASSISTED ILEOCECAL RESECTION
}

\author{
Maki MURAKAMI, Yasuhiro MUNAKATA, Ken HAYASHI, \\ Hideki NISHIMURA and Emi MACHIDA \\ Department of Surgery, Nagano Municipal Hospital
}

We report two cases of goblet cell carcinoid of the appendix presented with acute appendicitis, together with a review of the literature. A 35-year-old man and a 76-year-old woman were seen at the hospital because of right lower abdominal pain. They were diagnosed as having acute appendicitis, and underwent appendectomies. In both cases, the histological diagnosis was goblet cell carcinoid of the appendix. Because of diffuse involvement of the appendix and cecal involvement, a laparoscopy assisted ileocecal resection with lymphadenectomy was added on 37 th or 14th day after the initial operation in each case. There have been no signs of recurrence, as of 5 years after the operation in them. We believe that histological examination is necessary after appendectomy. 